\title{
MIR16-2 wt Allele
}

National Cancer Institute

\section{Source}

National Cancer Institute. MIR16-2 wt Allele. NCI Thesaurus. Code C81887.

The human MIR16-2 wild-type allele is located in the vicinity of 3q26.1 and is 80 bases in length. This allele, which encodes MIR16-2 pre-miRNA, plays a role in the regulation of gene expression. Alteration in the expression of this gene is associated with the development of both hepatocellular carcinoma and chronic lymphocytic leukemia. 